\title{
EXPECTATIONS OF PARTICIPATIVE LEADERSHIP BEHAVIOUR IN BOSNIA AND HERZEGOVINA
}

\author{
Danijela BOGDANIĆ \\ Chemnitz University of Technology, Faculty of Economics and Business Administration, Thüringer Weg 7, 09126 \\ Chemnitz, Germany. E-mail: danijela.bogdanic@s2008.tu-chemnitz.de
}

Accepted 20 November, 2012

\begin{abstract}
This paper elaborates on first quantitative results of an empirical study on participative leadership carried out among 158 middle managers from three sectors of industry in Bosnia and Herzegovina. The research builds up on a theoretical framework adapted from the GLOBE II research model, using the methodology and main instruments of the project. The main purpose of this paper is to explore the positions of Bosnian middle managers to what extent subordinates should be involved in the process of making and implementing decisions, as well as the impact of culture on the way managers perceive participation. Findings reveal that Bosnian middle managers are favourable towards participative leadership. Furthermore, significant impact of established cultural values and norms is recorded.
\end{abstract}

Keywords: leadership expectations, culture, GLOBE II research model, middle management, Bosnia and Herzegovina.

\section{INTRODUCTION}

One of the most significant functions performed by leaders is making and executing decisions. Participative leadership involves efforts by a leader to encourage and facilitate participation by others in making important decisions (Yukl, 2010, p. 137). In organizations, it is often necessary to involve others in the process of decision making in order to get decisions approved and implemented. Participative leaders not only guide group members but also participate actively in the group and acknowledge inputs from group members when making decisions and solving problems. Given that no leader can be a specialist in all fields, decisions reached in this way are more effective and precise. The issue of how much authority others are given to depends on the manager's preferences and attitudes, as well as on the nature of decision being made.

Participation can appear in many forms. Ever since the pioneering research conducted by Lewin, Lippitt, and White (1939) and Coch and French (1948), social scientists have proposed various categorizations of decision making procedures. Nevertheless, so far, there has not been any agreement regarding the definition or number of procedures necessary to make a decision (Heller and Yukl, 1969; Strauss, 1977; Tannenbaum and
Schmidt, 1958; Vroom and Yetton, 1973). The issue of how much authority others are given to depends on the manager's preferences and attitudes, as well as on the nature of decision being made. However, participative leadership can be seen as a continuum where, at one extreme, manager is making decisions independently (there is no participation), while on the other extreme manager delegates the authority and responsibility to subordinates, with several variations possible in between.

Having in mind insufficient level of knowledge and lack of empirical research in the area of leadership in Bosnia and Herzegovina (from now in Bosnia), I anticipate to contribute to the advancements of this field by providing insight into managers expectations regarding participative leadership. More accurately, the main purpose of this paper is to add to the knowledge of leadership in Bosnia by surveying the expectations of Bosnian middle managers to what extent subordinates should be involved in the process of making and implementing decisions. I will try to depict how leadership in Bosnia has evolved in the post-socialist era; e.g. whether a shift towards participative leadership has occurred in Bosnian society and organizations since the disintegration of Yugoslavia and socio-economic changes undertaken since the beginning of early $90 \mathrm{~s}$. Or, even though some changes are noticeable, but 
because of a cultural and historical heritage, high level of uncertainty on society and organizational levels, employees are steel favourable towards more autocratic leadership styles.

\section{RESEARCH FRAMEWORK}

In this paper, I investigate to what extent Bosnian middle managers expect leaders in Bosnia to involve others in the process of making and executing decisions. The research follows a theoretical framework adapted from the GLOBE II research model, using the methodology and main instruments of the project. In this paper I address to the following research questions: (a) are Bosnian middle managers favourable towards participative or autocratic leadership styles, (b) how similar/ divergent are the managers expectations regarding participative leadership based on several sociodemographic factors, (c) to what extent do norms, rules, patterns, rituals, procedures, and values endorsed within Bosnian society and industry significantly influence the way middle managers perceive participation, and (d) what is the relationship between society and organizational culture and participative leadership in Bosnian society and companies?

The background theory guiding this research is the (culturally endorsed) implicit leadership theory. The main presumption of this theory is that individuals have their own assumptions concerning features and behaviours of effective leaders, which are referred to as individual implicit leadership theories. These assumptions, beliefs, opinions, and convictions held by individuals influence the anticipations individuals have for leaders and their assessment of the leader's performances. It is believed that if the individual's leadership belief system is familiar, one could foresee whether that person would recognize other individual as an effective or ineffective leader, or a moral or evil leader (Lord and Maher, 1991). Basic presumption of this theory is that leadership is in the "eye of the beholder". An individual is perceived as a leader if their personality, attributes, virtues, and behaviours adequately match the observer's beliefs about leaders or if the observer attributes congregate success or failure to the activities of perceived leaders (Lord and Maher, 1991). GLOBE extended implicit leadership theory from the individual to collective (cultural) level of analysis. It is argued that the structure and content of individual belief systems will be shared among individuals in common cultures (House et. al., 2004). These constructs are labelled as "culturally endorsed implicit leadership theory (CLT)".

\section{RESEARCH METHODOLOGY}

The research on participative leadership is a part of a broader empirical research I have conducted in Bosnia with the main aim of exploring the relationship between characteristics of the society culture in Bosnia, the organizational culture of Bosnian enterprises and characteristics of the expected leadership in Bosnian companies. With the intention of implementing the research on participative leadership in Bosnia $\mathrm{I}$ used ten questions on leadership attributes from both GLOBE II quantitative survey questionnaires. The respondents were asked to value if the given statements inhibit or contribute to outstanding leadership. The answers were assessed with 7-point Lickert scale from a low of $1=$ "This behaviour or characteristic greatly inhibits a person from being an outstanding leader" to a high 7="This behaviour or characteristic contributes greatly to a person being an outstanding leader". Factor analysis of the single leadership attributes produced first order leadership factors. Following factor analysis of the first order leadership factors generated leadership dimension.

For the purpose of creating participative leadership dimension, initially, ten leadership attributes (bossy, autocratic, domineering, elitist, ruler, dictatorial, non-delegator, micro-manager, non-egalitarian, individually-oriented) were computed into two first order leadership factors (non-autocratic and participative leadership). Leadership attributes defining participative leadership dimension are presented in Table 1. The main remark regarding composition of the participative leadership dimension is the dominantly negative leadership attributes of which this leadership dimension is consisted. The respondents were asked to evaluate negative leader attributes, e.g. bossy, autocratic, ruler, dictatorial, etc. To generate participative leadership dimension, these leadership attributes were reverse-coded into a positive leadership items (e.g. "non-delegator" when reverse coded turns into "delegator", "non-egalitarian" into "egalitarian", etc). This may have a strong impact on the results/answers acquired by the analysis. More precisely, it does not automatically imply that an answer to a negative leader attribute, when reverse coded, will have the same value as if the respondents were asked directly to answer to positive leader attributes.

For the purpose of creating participative leadership dimension, initially, ten leadership attributes (bossy, autocratic, domineering, elitist, ruler, dictatorial, 
non-delegator, micro-manager, non-egalitarian, individually-oriented) were computed into two first order leadership factors (non-autocratic and participative leadership). Leadership attributes defining participative leadership dimension are presented in Table 1. The main remark regarding composition of the participative leadership dimension is the dominantly negative leadership attributes of which this leadership dimension is consisted. The respondents were asked to evaluate negative leader attributes, e.g. bossy, autocratic, ruler, dictatorial, etc. To generate participative leadership dimension, these leadership attributes were reverse-coded into a positive leadership items (e.g. "non-delegator" when reverse coded turns into "delegator", "non-egalitarian" into "egalitarian", etc). This may have a strong impact on the results/answers acquired by factor analysis. More precisely, it does not automatically imply that an answer to a negative leader attribute, when reverse coded, will have the same value as if the respondents were asked directly to answer to positive leader attributes.

\section{RESEARCH SAMPLE}

The quantitative data collection was administrated on the sample of 26 Bosnian companies from telecommunication sector, financial services, and food processing industry. The research was conducted from November 2008 till December 2009. Respondents were all middle level managers. Altogether 158 managers answered the questionnaires. Approximately $61.4 \%$ of the respondents were men, and $38.6 \%$ of them were women. The age of the respondents ranged from 25 years to 65 years, with an average age of around 40 years. As for the religious affiliation/ethnic belonging, $45.6 \%$ of respondents were Eastern Christian Orthodox/ Bosnian Serb, 34.2 \% Muslim/ Bosniaks, $16.5 \%$ Roman Catholics/ Bosnian Croats, and $3.8 \%$ declared belonging to other religions/ ethnic groups.

Table 1: Leadership attributes and factors comprising participative leadership dimension

\begin{tabular}{|c|c|c|c|}
\hline $\begin{array}{l}\text { Leadership } \\
\text { dimension }\end{array}$ & $\begin{array}{l}\text { Leadership } \\
\text { factors }\end{array}$ & $\begin{array}{l}\text { Leadership } \\
\text { attributes }\end{array}$ & Definition of leadership attributes \\
\hline \multirow{10}{*}{$\begin{array}{c}\text { Participative } \\
5.37 \\
\text { (Definition: } \\
\text { Participative } \\
\text { leadership is the } \\
\text { degree to which } \\
\text { managers involve } \\
\text { others in making and } \\
\text { implementing } \\
\text { decisions ) }\end{array}$} & \multirow{4}{*}{$\begin{array}{l}\text { Non-autocratic } \\
\text { (reverse scored) } \\
4.65\end{array}$} & $\begin{array}{c}\text { Non-Delegator } \\
3.12 \\
\end{array}$ & $\begin{array}{l}\text { Tells subordinates what to do in a commanding } \\
\text { way }\end{array}$ \\
\hline & & $\begin{array}{c}\text { Micro-Manager } \\
3.00 \\
\end{array}$ & Makes decisions in dictatorial way \\
\hline & & $\begin{array}{c}\text { Non-Egalitarian } \\
1.70 \\
\end{array}$ & Inclined to dominate others \\
\hline & & $\begin{array}{l}\text { Individually- } \\
\text { Oriented } \\
2.40 \\
\end{array}$ & $\begin{array}{l}\text { Believes that a small number of people with } \\
\text { similar backgrounds are superior and should } \\
\text { enjoy privileges }\end{array}$ \\
\hline & \multirow{6}{*}{$\begin{array}{l}\text { Participative } \\
\text { (reverse scored) } \\
5.44\end{array}$} & $\begin{array}{c}\text { Bossy } \\
4.32 \\
\end{array}$ & $\begin{array}{l}\text { Is in charge and does not tolerate disagreement } \\
\text { or questioning, gives orders }\end{array}$ \\
\hline & & $\begin{array}{c}\text { Autocratic } \\
3.35\end{array}$ & Forces her/his values and opinions on others \\
\hline & & $\begin{array}{l}\text { Domineering } \\
5.75\end{array}$ & $\begin{array}{l}\text { Unwilling or unable to relinquish control of } \\
\text { projects or tasks }\end{array}$ \\
\hline & & $\begin{array}{c}\text { Elitist } \\
2.66\end{array}$ & $\begin{array}{l}\text { An extremely close supervisor, one who insists } \\
\text { on making all decisions }\end{array}$ \\
\hline & & $\begin{array}{c}\text { Ruler } \\
4.56\end{array}$ & $\begin{array}{l}\text { Believes that all individuals are not equal and } \\
\text { only some should have equal rights and } \\
\text { privileges }\end{array}$ \\
\hline & & $\begin{array}{c}\text { Dictatorial } \\
2.73\end{array}$ & $\begin{array}{l}\text { Concerned with and places high value on } \\
\text { preserving individual rather than group needs }\end{array}$ \\
\hline
\end{tabular}

\section{EMPIRICAL FINDINGS}

Participative leadership is viewed positively by Bosnian middle managers (see Table 1). On the other hand, autocratic leadership style (3.35) is perceived in a negative way and rejected by middle managers. The score of 5.37 (on a 7-point Lickert scale) positions participative leadership as 3rd among six second order leadership dimensions developed for the project GLOBE. Within Bosnian society, participative leadership is considered to be one of the important dimensions for effective leadership, but not as strongly supported as charismatic/value-based and team oriented leadership. Moreover, empirical findings disclose the desire of Bosnian middle managers for more 
participation in the process of decision making. Then again, managers in Bosnia who are not delegating and not engaging subordinates in the process of creating and implementing decisions are seen quite negatively. Furthermore, leaders who are unwilling or unable to hand over control of projects or tasks, who insist on making all decisions, who are concentrated on preserving individual goals rather than group needs, and who believe that all individuals are not equal and only some should have equal rights and privileges are seen in the negative way.

Overall findings indicate preferences of Bosnian middle managers regarding participatory leadership styles as a tool towards higher leader effectiveness. On the other hand, if individual leader attributes are analysed, surprisingly, middle managers value quite positively leader attributes ruler (4.56), domineering (5.76), and bossy (4.32). At the same time, they expect effective leaders to place high values on the group needs, to delegate, to be egalitarian, and not to impose his/hers values and opinions on others, which is conflicting to the attributes ruler, domineering, and bossy. Perhaps, it will be a task of future studies on leadership in Bosnia to disclose the factors standing behind these preferences of Bosnian managers.

Statistical analysis did not reveal significant divergences on leadership attributes and factors amongst Bosnian managers based on their age, gender and religion. Nevertheless, Bosnian Croats expect an efficient leader to be less autocratic and more participative than Bosnian Serbs and Bosniaks.
Younger managers are more tolerant towards nonparticipative leadership than old and middle-age managers. Female managers were found to anticipate an outstanding leader to be less autocratic and to encourage and facilitate participation of others in making decisions than male managers. Further analysis disclosed statistically significant divergence on leader attribute "nondelegator/delegator" amongst managers from three sectors of industry $(\mathrm{F}=3.069$, sig. $=.049)$. Bosnian managers are expected to delegate the most in financial services, the least in telecommunications, while the scores of middle managers from food processing industry are in-between.

GLOBE findings disclose that participative leadership is viewed positively in countries from Eastern Europe cluster (mean score is higher than 4.50 for each country whereas cluster average is 5.08). Albania, Georgia, and Russia did not support participative leadership as strongly as remaining Eastern European countries. When Bosnia data are compared with the GLOBE findings from Eastern Europe cluster, it can be perceived that Bosnia shows closest resemblance to Slovenia (score difference is -0.05). Bearing in mind geographic immediacy, same climate zone, religious and linguistic genesis, similar cultural and historical heritage, and the fact that both countries were previously two republics of former Yugoslavia, similarity in scores between Bosnia and Slovenia was anticipated. On the other hand, the biggest score divergence is registered amongst Bosnia and Albania (score difference is -0.87), and between Bosnia and Greece (score difference is +0.44 ).

Table 2: Correlations between nine cultural dimensions and participative leadership

\begin{tabular}{|c|c|c|c|c|c|}
\hline \multirow{3}{*}{$\begin{array}{l}\text { Leadership } \\
\text { Dimension }\end{array}$} & \multirow{3}{*}{$\begin{array}{c}\text { Culture } \\
\text { Dimensions }\end{array}$} & \multicolumn{4}{|c|}{ Culture Dimensions } \\
\hline & & \multicolumn{2}{|c|}{ Societal } & \multicolumn{2}{|c|}{ Organizational } \\
\hline & & Practices & Values & Practices & Values \\
\hline \multirow{9}{*}{ Participative } & Performance Orientation & -.049 & $.098 *$ & -.055 & .015 \\
\hline & Future Orientation & $.072 *$ & .071 & -.044 & $-.151 *$ \\
\hline & Humane Orientation & $.083 *$ & $.172 * *$ & $.092 *$ & $.349 * *$ \\
\hline & Institutional Collectivism & $.217 * *$ & $-.094 *$ & .004 & $-.096 *$ \\
\hline & In-Group Collectivism & $-.141 *$ & .033 & $-.106 * *$ & .029 \\
\hline & Assertiveness & $-.309 * *$ & -.039 & -.016 & $-.241 * *$ \\
\hline & Gender Egalitarianism & .154 & $.126 *$ & $-.165 * *$ & $.145 * *$ \\
\hline & Power Distance & -.038 & $-.183 * *$ & -.072 & $.195 * *$ \\
\hline & Uncertainty Avoidance & -.022 & $-.138 * *$ & .043 & $.319 * *$ \\
\hline
\end{tabular}

Note: $* *=$ Correlation is significant at the 0.01 level (2-tailed); $*=$ Correlation is significant at the 0.05 level (2- tailed) 


\section{CORRELATIONS BETWEEN CULTURE AND PARTICIPATIVE LEADERSHIP}

From Table 2 it can be perceived that participative leadership is influenced by numerous society and organizational cultural dimensions. Participative leadership is mostly influenced by humane orientation, institutional collectivism, gender egalitarianism, assertiveness, and power distance. The research results point out that the most important cultural dimension predicting this leadership variable on both national (practices and values) and organizational (practices and values) level is humane orientation. The strongest relation was recorded between participative leadership dimension and organizational humane orientation values $(R=0.349, p<0.01)$. Even though this is the strongest correlation it is somewhat modest. Next comes correlations between this leadership variable and organizational uncertainty avoidance values $(R$ $=0.319, \mathrm{p}<0.01)$, national assertiveness practices $(\mathrm{R}=-0.309, \mathrm{p}<0.01)$, organizational assertiveness values $(\mathrm{R}=-0.241, \mathrm{p}<0.01)$, and society institutional collectivism practices $(\mathrm{R}=-0.217, \mathrm{p}<$ $0.01)$.

\section{CONCLUSION}

Findings presented in this paper clearly reflect preferences of Bosnian middle managers for participation as an important instrument for effective leadership in Bosnia, and, at the same time, rejecting autocratic leadership style. This indicates the move of Bosnian managers from a centrally-planned economy, party appointed supervisors and fake collective contribution to more participative leadership styles.

These data provide an interesting material for a better understanding of managers' preferences regarding participation in Bosnia. Its application can lead to competitive advantage of Bosnian companies. Managers can utilize these findings in everyday life in order to increase individual and organizational effectiveness. However, drawing conclusions from this research, one should be aware that it covered an explicit group of respondents middle level managers from the three sectors of industry: telecommunication sector, financial services, and food processing industry. Moreover, the study includes only 158 middle managers, which is hardly representative of the entire Bosnian population. This study presents only a beginning of an understanding of leadership within Bosnian society and industry. The findings presented here are merely a scratch on the surface of a very complex phenomenon. It remains for the future studies to deepen the knowledge on leadership in Bosnia and Herzegovina and factors influencing leadership.

\section{REFERENCES}

Coch, L., \& French, J. R. P., Jr. (1948). Overcoming resistance to change. Human Relations, 1, 512532.

Heller, F. A., \& Yukl, A. (1969). Participation, managerial decision-making, and situational variables. Organizational Behavior and Human Performance, 4(3), 227-241.

House, R. J., Hanges, P. J., Javidan, M., Dorfman, P. W., \& Gupta, V. (2004). Culture, Leadership and Organizations: The GLOBE Study of 62 Societies. Thousand Oaks, California: Sage Publications, Inc.

Lewin, K., LIippit, R., \& White, R. K. (1939). Patterns of aggressive behaviour in experimentally created social climates. Journal of Social Psychology(10), 271-301.

Lord, R., \& Maher, K. J. (1991). Leadership and information processing: Linking perceptions and performance. Boston: Unwin-Everyman.

Strauss, G. (1977). Union Government in the U.S.: Research Past and future. Industrial Relations, 16(2), 215-242.

Tannenbaum, R., \& Schmidt, W. (1958, March-April). How to choose a leadership pattern. Harvard Business Review, 36(2), 95-101.

Vroom, V. H., \& Yetton, P. W. (1973). Leadership and Decision-Making: University of Pittsburgh Press.

Yukl, G. (2010). Leadership in organizations (7th ed.). Upper Saddle River, New York: Prentice Hall. 